\title{
Aluminum Resistance among Seeded Bermudagrasses
}

\author{
Haibo Liu \\ Department of Horticulture, Clemson University, Clemson, SC 29634-0375
}

Additional index words. aluminum toxicity, acid soil, aluminum tolerance

\begin{abstract}
Aluminum toxicity is a major limiting factor for turfgrass establishment and growth when soil $\mathbf{p H}$ is $\mathbf{< 5 . 0}$. Limited information on aluminum resistance is available among warm-season turfgrasses and these turfgrasses often grow in the areas with acid soil conditions. The objectives of this study were 1) to evaluate seeded bermudagrass (Cynodon dactylon $\mathbf{L}$.) cultivars for the ability to tolerate a high level of aluminum and 2) to measure the extent of aluminum damage to the root systems. In total, 16 bermudagrass cultivars were evaluated under greenhouse conditions using a solution culture and an acid Tatum soil (Clayey, mixed, thermic, typic, Hapludult). The soil had pH $4.4 \%$ and $69 \%$ exchangeable aluminum. A concentration of $640 \mu \mathrm{M}$ aluminum and a pH 4.0 was used for solution culture. The grasses were grown for $\mathbf{2 8}$ days in solution culture; 28 days in the acid Tatum soil; and 78 days in the acid Tatum soil before harvesting. Aluminum resistance was determined by measuring the longest root length, the longest shoot length, dry root weight, dry shoot weight, and shoot to root ratio in comparing the control to obtain the relative $\mathrm{Al}$ resistance among the cultivars. The results indicate that seeded bermudagrass cultivars differ in their aluminum resistance.
\end{abstract}

Bermudagrass is the most popular warmseason turfgrass in the world. Soil acidity is one of the problems associated with some southern areas and the transition zone where bermudagrass grows. Under acid soil conditions, warm-season turfgrass will face more stresses such as nutrient deficiency, poor drought resistance, and winter-kill in the transition zone (Duncan, 2000; Duncan and Carrow, 1999; Duncan and Shuman, 1993; Liu, 2001). Seeded bermudagrass has been a new turfgrass for medium to low maintenance turf in the southern and transitional areas. The new breakthroughs of transgenic $\mathrm{Al}$ resistant plants or organisms (Andersson, 1988; De la Fuente et al., 1997; De la Fuente-Martinez and Herrera-Estrella, 1999; Ezaki et al., 1999, 2000; Taylor 1988, 1991) provide the promising future for turfgrass enhancement to acid soil stress by using genetic engineering techniques. Aluminum toxicity has been reported in perennial crops and turfgrasses (Duncan, 2000; Foy, 1988, 1992; Kochian, 1995, Kochian and Jones, 1999; Kochian et al., 2004; Murray and Foy, 1978). The genetic diversity of bermudagrass may be another positive aspect for breeding bermudagrass for $\mathrm{Al}$ resistance (Taliaferro, 1995). However, the information of acid resistance among bermudagrass cultivars is limited.

Received for publication 14 Jan. 2004. Accepted for publication 14 June 2004. Many thanks to Joseph Heckman, James Murphy, C.R. Funk, B.B. Clarke, and the New Jersey Agricultural Experiment Station for the support and encouragement during this study; the Center of Turfgrass Science at Rutgers for providing the facilities and funding for this project; the seed supplies from the NTEP program and Simplot (Jacklin Seed); Dave Starner (Agricultural Experiment Station of Virginia Polytech. \& State University) for providing the acid Tatum subsoil; and David Stiles and David Coffey from Western Kentucky University for reviewing the manuscript.

Associate professor; e-mail haibol@clemson.edu.
The objectives of this study were 1) to evaluate 16 seeded bermudagrass (Cynodon dactylon L.) cultivars for the ability to tolerate a high level of aluminum by using different culture methods with variable time length and 2) to measure to measure the extent of aluminum damage to root and shoot growth.

\section{Materials and Methods}

Three growth media (solution culture, acid Tatum subsoil, and atop-dressing sand) were used to screen the relative $\mathrm{Al}$ resistance among the bermudagrass cultivars. The seeds were from the NETP program and Simplot (Jacklin Seed). The experiments were conducted in two different locations with similar greenhouse conditions. Greenhouse day/night temperatures were set for about $28 / 22^{\circ} \mathrm{C}$. The experimental design was a randomized complete block with three replications. The screenings of 16 bermudagrass cultivars using the solution culture and the acid Tatum subsoil culture were conducted at, Cook College, Rutgers University, New Brunswick, N.J.

Solution culture. Sixteen bermudagrass cultivars (Tables 1, 2, and 3) were seeded at a rate of $2.0 \mathrm{~g} \cdot \mathrm{m}^{-2}$ and grown for $28 \mathrm{~d}$ in a modified 1/4-strength Hoagland's nutrient solution (Hoagland and Arnon, 1950). A floating mesh was used to support the plants as described by Liu et al. (1995). Aluminum was added to solution as $\mathrm{Al}_{2}\left(\mathrm{SO}_{4}\right)_{3} 18 \mathrm{H}_{2} \mathrm{O}$ at a concentration of 0 (the control) or $640 \mu \mathrm{M}$. The $\mathrm{pH}$ of both the control and the $640 \mu \mathrm{M} \mathrm{Al}$ solutions was adjusted daily to $4.0( \pm 0.1)$ using $0.1 \mathrm{M} \mathrm{HCl}$ or $0.1 \mathrm{M} \mathrm{NaOH}$. All solutions were changed every four days. Deionised distilled water was used to make all solutions. The solution was aerated except for the first week after seeding. All the treatments including the control were replicated three times.

The acid Tatum subsoil culture. Two different time lengths were used for the acid
Tatum subsoil screening: a 28-d culture using conetainers containing about $250 \mathrm{~g}$ of the soil and a 78-d culture using pots containing about $4 \mathrm{~kg}$ of soil. The acid Tatum subsoil (Clayey, mixed, thermic, typic, Hapludult) from Orange, Va., had a $\mathrm{pH}$ of 4.4 (1 soil : 1 water ratio), a cation exchange capacity of $13.0 \mathrm{cmol} \cdot \mathrm{kg}^{-1}$, and $8.82 \mathrm{cmol} \cdot \mathrm{kg}^{-1}$ of $\mathrm{KCl}$-extractable $\mathrm{Al}$. Other cations present in the soil included $\mathrm{Na}$ at $0.36 \mathrm{cmol} \cdot \mathrm{kg}^{-1} ; \mathrm{Mg}$ at $0.64 \mathrm{cmol} \cdot \mathrm{kg}^{-1} ; \mathrm{Ca}$ at $0.21 \mathrm{cmol} \cdot \mathrm{kg}^{-1}$; and $\mathrm{K}$ at $0.32 \mathrm{cmol} \cdot \mathrm{kg}^{-1}$, as determined by extraction with $1 \mathrm{~N} \mathrm{NH}_{4} \mathrm{OAc}$ at $\mathrm{pH}$ 7.0. The soil was treated with either 0 or $3,500 \mathrm{mg} \cdot \mathrm{kg}^{-1}$ of $\mathrm{CaCO}_{3}$; liming the soil increasing the $\mathrm{pH}$ to 6.3 with lime used as the control. Seeds were planted 3 weeks after liming the soil. Fertilization with $\mathrm{NH}_{4} \mathrm{NO}_{3}$ and $\mathrm{KH}_{2} \mathrm{PO}_{4}$ added $\mathrm{N}, \mathrm{P}$, and $\mathrm{K}$ at 100,109 , and $137 \mathrm{mg} \cdot \mathrm{kg}^{-1}$ of the soil, respectively for both limed and nonlimed soils. Tap water ( $\mathrm{pH}$ 6.9) was added as needed to avoid drought stress. All the treatments including the control were replicated three times.

Data collection and analysis. All treatments in the three methods described were replicated three times. The measurement of root length and shoot length were conducted immediately after harvesting. The dry weight of roots and shoots were obtained after dried at $65{ }^{\circ} \mathrm{C}$ for $48 \mathrm{~h}$ washed off soil.

Relative root length and relative shoot length were obtained by using such a formula: length with $\mathrm{Al} /$ length without $\mathrm{Al} \times 100$ (Liu et al., 1995). The relative root mass and relative shoot mass were obtained by using a such formula: [(root or shoot mass/number of plants in a single culture) with $\mathrm{Al} /$ (root or shoot mass/number of plants in a single culture) without $\mathrm{Al}] \times 100$. In this case, the relative mass was based on one single plant instead of a culture unit with different number of plants. However, for the 78-d acid Tatum soil culture, it was impossible to separate individual plants. Each pot was seeded with 30 seeds and the relative mass was obtained based on individual pots.

The main reason to have such relative values for measurement of $\mathrm{Al}$ toxicity is because that the control $\mathrm{pH}$ is at 4.0 , which is a stressful condition for most plants. The use of such relative values will separate the stressful condition of a lower $\mathrm{pH}(4.0)$ and $\mathrm{Al}$ toxicity in this study.

The values of the screening parameters were subjected to ANOVA procedures for each medium, and cultivar means were separated by Duncan's multiple range test as a randomized complete block design. All statistical computations were conducted by using ANOVA procedures within the Statistical Analysis System (SAS), a PC version.

\section{Results and Discussion}

Solution culture. The growth of all cultivars screened was significantly reduced as affected by Al based on all parameters measured. However, 'FMC 3-91' exhibited a greater resistance among the 16 cultivars, while 'Guymon' and 'OKS 91-11' even failed to germinate (Table 1). The parameters used for the screening were 
Table 1. Relative growth of 16 bermudagrass cultivars grown for $28 \mathrm{~d}$ in solution culture containing $640 \mu \mathrm{M} \mathrm{Al}$ at $\mathrm{pH} 4.0$

\begin{tabular}{|c|c|c|c|c|c|c|}
\hline Cultivar & $\begin{array}{c}\text { Relative } \\
\text { root } \\
\text { length } \\
(\%)\end{array}$ & $\begin{array}{c}\text { Relative } \\
\text { shoot } \\
\text { length } \\
(\%)\end{array}$ & $\begin{array}{c}\text { Relative } \\
\text { root } \\
\text { mass } \\
(\%)\end{array}$ & $\begin{array}{c}\text { Relative } \\
\text { shoot } \\
\text { mass } \\
(\%)\end{array}$ & $\begin{array}{c}\text { Shoot } \\
\text { to root } \\
\text { ratio } \\
\text { with } \mathrm{Al}\end{array}$ & $\begin{array}{c}\text { Shoot } \\
\text { to root } \\
\text { ratio } \\
\text { without } \mathrm{Al}\end{array}$ \\
\hline Cheyenne & $23.7 b^{z}$ & $26.8 \mathrm{ab}$ & $13.8 \mathrm{bc}$ & $24.3 \mathrm{ac}$ & $23 . \mathrm{b}$ & 5.8 \\
\hline OKS 91-1 & $2.1 \mathrm{~cd}$ & 5.7 ef & $18.97 \mathrm{ab}$ & $29.64 \mathrm{abc}$ & $370.7 \mathrm{a}$ & 6.37 \\
\hline FMC 3-91 & $43.62 \mathrm{a}$ & $34.82 \mathrm{a}$ & $26.64 \mathrm{a}$ & $43.76 \mathrm{a}$ & $7.8 \mathrm{~b}$ & 5.97 \\
\hline 90173 & $6.42 \mathrm{bcd}$ & $11.88 \mathrm{~b}-\mathrm{f}$ & $6.68 \mathrm{bc}$ & $13.28 \mathrm{bcd}$ & $153.5 \mathrm{ab}$ & 4.96 \\
\hline A. $\operatorname{common}^{\mathrm{y}}$ & $18.27 \mathrm{bc}$ & $22.14 \mathrm{a}-\mathrm{d}$ & $15.40 \mathrm{ab}$ & $24.37 \mathrm{abc}$ & $235.2 \mathrm{ab}$ & 6.23 \\
\hline FMC 1-90 & $13.86 \mathrm{bcd}$ & $23.72 a b c$ & $9.81 \mathrm{bc}$ & $16.51 \mathrm{bcd}$ & $102.7 \mathrm{ab}$ & 5.66 \\
\hline Sonesta & $14.00 \mathrm{bcd}$ & $17.79 \mathrm{~b}-\mathrm{e}$ & $13.16 \mathrm{abc}$ & $23.10 \mathrm{a}-\mathrm{d}$ & $178.5 \mathrm{ab}$ & 5.97 \\
\hline Sundevil & $20.00 \mathrm{bc}$ & $25.64 a b c$ & $10.04 \mathrm{bc}$ & $16.16 \mathrm{bcd}$ & $141.2 \mathrm{ab}$ & 6.49 \\
\hline J-192 & $15.75 \mathrm{bcd}$ & $12.37 \mathrm{~b}-\mathrm{f}$ & $14.55 \mathrm{ab}$ & $24.95 \mathrm{abc}$ & $134.3 \mathrm{ab}$ & 5.93 \\
\hline FMC 2-90 & $11.55 \mathrm{bcd}$ & $15.59 \mathrm{~b}-\mathrm{e}$ & $13.00 \mathrm{abc}$ & $20.59 \mathrm{a}-\mathrm{d}$ & $123.2 \mathrm{ab}$ & 5.70 \\
\hline Jackpot & $9.55 \mathrm{bcd}$ & $10.86 \mathrm{c}-\mathrm{f}$ & $18.59 \mathrm{ab}$ & $35.07 \mathrm{ab}$ & $74.7 \mathrm{ab}$ & 5.82 \\
\hline FMC 5-91 & $8.08 \mathrm{bcd}$ & $13.99 \mathrm{~b}-\mathrm{f}$ & $11.43 \mathrm{bc}$ & $19.63 \mathrm{bcd}$ & $42.4 \mathrm{~b}$ & 5.77 \\
\hline FMC 6-91 & $19.36 \mathrm{bc}$ & $16.54 \mathrm{~b}-\mathrm{e}$ & $11.43 \mathrm{bc}$ & $24.51 \mathrm{abc}$ & $46.7 \mathrm{~b}$ & 6.49 \\
\hline Guymon & $0.00 \mathrm{~d}$ & $0.00 \mathrm{f}$ & $0.00 \mathrm{c}$ & $0.00 \mathrm{~d}$ & --- & 6.26 \\
\hline $\mathrm{J}-27$ & $6.62 \mathrm{bcd}$ & $8.65 \mathrm{ef}$ & $6.10 \mathrm{bc}$ & $9.02 \mathrm{~cd}$ & $78.0 \mathrm{ab}$ & 6.78 \\
\hline OKS 91-11 & $0.00 \mathrm{~d}$ & $0.00 \mathrm{f}$ & $0.00 \mathrm{c}$ & $0.00 \mathrm{~d}$ & --- & 5.90 \\
\hline
\end{tabular}

${ }^{\text {z}}$ Values within a column followed by the same letter are not different at the $5 \%$ level of probability based on Duncan's multiple range test.

${ }^{\mathrm{y}} \mathrm{A}$. common $=$ Arizona common.

Table 2. Relative growth of 16 bermudagrass cultivars grown for $28 \mathrm{~d}$ in nonlimed acid Tatum subsoil at a pH of 4.4

\begin{tabular}{|c|c|c|c|c|c|c|}
\hline Cultivar & $\begin{array}{c}\text { Relative } \\
\text { root } \\
\text { length } \\
(\%)\end{array}$ & $\begin{array}{c}\text { Relative } \\
\text { shoot } \\
\text { length } \\
(\%)\end{array}$ & $\begin{array}{c}\text { Relative } \\
\text { root } \\
\text { mass } \\
(\%)\end{array}$ & $\begin{array}{c}\text { Relative } \\
\text { shoot } \\
\text { mass } \\
(\%)\end{array}$ & $\begin{array}{c}\text { Shoot } \\
\text { to root } \\
\text { ratio } \\
\text { with Al }\end{array}$ & $\begin{array}{c}\text { Shoot } \\
\text { to root } \\
\text { ratio } \\
\text { without } \mathrm{Al}\end{array}$ \\
\hline Cheyenne & $80.08 \mathrm{a}^{\mathrm{z}}$ & $67.72 \mathrm{ab}$ & $69.10 \mathrm{ab}$ & $48.24 \mathrm{a}-\mathrm{d}$ & $1.85 \mathrm{~b}$ & $2.68 \mathrm{c}-\mathrm{f}$ \\
\hline OKS 91-1 & $68.69 \mathrm{a}-\mathrm{d}$ & $62.70 \mathrm{a}-\mathrm{d}$ & 44.29 bc & $32.02 \mathrm{ef}$ & $2.07 \mathrm{~b}$ & $2.90 \mathrm{c}-\mathrm{f}$ \\
\hline FMC 3-91 & $75.92 \mathrm{abc}$ & $64.01 \mathrm{abc}$ & $55.99 \mathrm{abc}$ & $46.63 \mathrm{a}-\mathrm{d}$ & $2.31 \mathrm{~b}$ & $2.65 \mathrm{c}-\mathrm{f}$ \\
\hline 90173 & $36.43 \mathrm{e}$ & 38.51 ef & $33.79 \mathrm{~cd}$ & $28.97 \mathrm{fg}$ & $3.90 \mathrm{~b}$ & $3.35 \mathrm{~b}-\mathrm{d}$ \\
\hline A. common $^{y}$ & $83.92 \mathrm{a}$ & $76.79 \mathrm{ab}$ & $66.08 \mathrm{ab}$ & $54.69 \mathrm{ab}$ & $2.37 \mathrm{~b}$ & $2.90 \mathrm{c}-\mathrm{f}$ \\
\hline FMC 1-90 & $79.69 \mathrm{ab}$ & $77.23 \mathrm{ab}$ & $63.50 \mathrm{ab}$ & $47.94 \mathrm{a}-\mathrm{d}$ & $1.97 \mathrm{~b}$ & $2.56 \mathrm{ef}$ \\
\hline Sonesta & $76.05 \mathrm{abc}$ & $78.23 \mathrm{a}$ & $71.58 \mathrm{a}$ & $58.23 \mathrm{a}$ & $2.10 \mathrm{~b}$ & $2.53 \mathrm{~d}-\mathrm{f}$ \\
\hline Sundevil & $71.11 \mathrm{a}-\mathrm{d}$ & $76.22 \mathrm{ab}$ & $71.41 \mathrm{a}$ & $55.23 \mathrm{ab}$ & $1.98 \mathrm{~b}$ & 2.55 ef \\
\hline J-192 & $56.83 \mathrm{~d}$ & $51.08 \mathrm{cde}$ & $48.53 \mathrm{abc}$ & $39.86 \mathrm{c}-\mathrm{f}$ & $3.26 \mathrm{~b}$ & $3.59 \mathrm{abc}$ \\
\hline FMC 2-90 & $67.13 \mathrm{a}-\mathrm{d}$ & $62.15 \mathrm{bcd}$ & $67.12 \mathrm{ab}$ & $49.69 \mathrm{abc}$ & $2.53 \mathrm{~b}$ & $3.56 \mathrm{~b}-\mathrm{d}$ \\
\hline Jackpot & $61.41 \mathrm{bcd}$ & $47.50 \mathrm{de}$ & $49.27 \mathrm{abc}$ & $45.94 \mathrm{a}-\mathrm{d}$ & $4.26 \mathrm{~b}$ & $4.18 \mathrm{ab}$ \\
\hline FMC 5-91 & $59.57 \mathrm{~cd}$ & 48.79 cde & 44.27 bc & $35.98 \mathrm{def}$ & $2.57 \mathrm{~b}$ & $3.04 \mathrm{c}-\mathrm{f}$ \\
\hline FMC 6-91 & $59.69 \mathrm{~cd}$ & $72.22 \mathrm{ab}$ & $63.88 \mathrm{ab}$ & $53.40 \mathrm{ab}$ & $2.83 \mathrm{~b}$ & $3.21 \mathrm{~b}-\mathrm{f}$ \\
\hline Guymon & $21.42 \mathrm{ef}$ & $27.08 \mathrm{fg}$ & $8.04 \mathrm{e}$ & $42.34 \mathrm{~b}-\mathrm{e}$ & $113.90 \mathrm{a}$ & $4.57 \mathrm{a}$ \\
\hline $\mathrm{J}-27$ & $29.14 \mathrm{e}$ & 38.84 ef & $10.34 \mathrm{de}$ & 29.64 efg & $7.03 \mathrm{~b}$ & $2.28 \mathrm{f}$ \\
\hline OKS 91-11 & $10.50 \mathrm{f}$ & $16.18 \mathrm{~g}$ & $1.61 \mathrm{e}$ & $17.25 \mathrm{~g}$ & $30.33 \mathrm{~b}$ & $2.85 \mathrm{c}-\mathrm{f}$ \\
\hline
\end{tabular}

${ }^{\mathrm{z}}$ Values within a column followed by the same letter are not different at the 5\% level of probability based on Duncan's multiple range test.

${ }^{\mathrm{y}} \mathrm{A}$. common $=$ Arizona common.

Table 3. Relative growth of 16 bermudagrass cultivars grown for $78 \mathrm{~d}$ in nonlimed acid Tatum subsoil at a pH of 4.4

\begin{tabular}{|c|c|c|c|c|c|c|}
\hline Cultivar & $\begin{array}{c}\text { Root } \\
\text { dry wt } \\
\text { without Al } \\
(\mathrm{g})\end{array}$ & $\begin{array}{c}\text { Shoot } \\
\text { dry wt } \\
\text { without Al } \\
\text { (g) }\end{array}$ & $\begin{array}{c}\text { Relative } \\
\text { root wt } \\
\text { with Al } \\
(\%)\end{array}$ & $\begin{array}{c}\text { Relative } \\
\text { shoot wt } \\
\text { with Al } \\
(\%)\end{array}$ & $\begin{array}{l}\text { Shoot } \\
\text { to root } \\
\text { ratio } \\
\text { with } \mathrm{Al}\end{array}$ & $\begin{array}{c}\text { Shoot } \\
\text { to root } \\
\text { ratio } \\
\text { without } \mathrm{Al}\end{array}$ \\
\hline Cheyenne & 2.32 & $18.61 \mathrm{~b}-\mathrm{e}^{\mathrm{z}}$ & $124.52 \mathrm{a}$ & $60.69 \mathrm{a}$ & $3.56 \mathrm{~b}$ & 8.38 \\
\hline OKS 91-1 & 2.37 & $19.33 \mathrm{bc}$ & $102.54 \mathrm{ab}$ & $47.96 \mathrm{ab}$ & $3.97 \mathrm{~b}$ & 8.56 \\
\hline FMC 3-91 & 2.78 & $19.01 \mathrm{bcd}$ & $98.13 \mathrm{ab}$ & $51.90 \mathrm{ab}$ & $3.13 \mathrm{~b}$ & 7.54 \\
\hline 90173 & 2.33 & $16.38 \mathrm{~b}-\mathrm{g}$ & $89.48 \mathrm{ab}$ & $48.56 \mathrm{ab}$ & $3.86 \mathrm{~b}$ & 7.47 \\
\hline A. $\operatorname{common}^{\mathrm{y}}$ & 3.52 & $20.17 \mathrm{ab}$ & $79.59 \mathrm{bcd}$ & $43.40 \mathrm{ab}$ & $2.63 \mathrm{~b}$ & 5.98 \\
\hline FMC 1-90 & 2.72 & $19.42 a b c$ & $78.51 \mathrm{bcd}$ & $42.15 \mathrm{ab}$ & $3.54 \mathrm{~b}$ & 7.71 \\
\hline Sonesta & 2.66 & $20.03 \mathrm{ab}$ & $69.83 \mathrm{~b}-\mathrm{e}$ & $38.68 \mathrm{ab}$ & $3.90 \mathrm{~b}$ & 7.88 \\
\hline Sundevil & 3.77 & $23.29 \mathrm{a}$ & $53.89 \mathrm{~b}-\mathrm{e}$ & $29.74 \mathrm{ab}$ & $3.35 \mathrm{~b}$ & 6.78 \\
\hline J-192 & 2.22 & 15.00 efg & $48.68 \mathrm{e}-\mathrm{f}$ & $28.29 \mathrm{ab}$ & $3.75 \mathrm{~b}$ & 7.61 \\
\hline FMC 2-90 & 2.35 & $13.44 \mathrm{fg}$ & $43.83 \mathrm{c}-\mathrm{f}$ & $32.33 \mathrm{ab}$ & $4.18 \mathrm{~b}$ & 5.86 \\
\hline Jackpot & 2.80 & $15.78 \mathrm{c}-\mathrm{g}$ & $42.17 \mathrm{def}$ & $20.92 \mathrm{ab}$ & $2.58 \mathrm{~b}$ & 6.23 \\
\hline FMC 5-91 & 3.87 & $14.19 \mathrm{fg}$ & 38.43 efg & $39.65 \mathrm{ab}$ & $3.74 \mathrm{~b}$ & 5.73 \\
\hline FMC 6-91 & 3.65 & $17.01 \mathrm{~b}-\mathrm{f}$ & 33.87 efg & $33.75 \mathrm{ab}$ & $4.53 \mathrm{~b}$ & 5.21 \\
\hline Guymon & 3.26 & $15.08 \mathrm{~d}-\mathrm{g}$ & $8.34 \mathrm{~g}$ & $0.52 \mathrm{~b}$ & $3.13 \mathrm{~b}$ & 5.39 \\
\hline $\mathrm{J}-27$ & 1.97 & $13.91 \mathrm{fg}$ & $4.79 \mathrm{~g}$ & $1.60 \mathrm{~b}$ & $3.05 \mathrm{~b}$ & 7.08 \\
\hline OKS 91-11 & 2.37 & $19.33 \mathrm{bc}$ & $0.09 \mathrm{~g}$ & $0.08 \mathrm{~b}$ & $70.92 \mathrm{a}$ & 7.65 \\
\hline
\end{tabular}

${ }^{\mathrm{z}}$ Values within a column followed by the same letter are not different at the $5 \%$ level of probability based on Duncan's multiple range test.

${ }^{\mathrm{y}} \mathrm{A}$. common = Arizona common. 
adequate and similar to other findings (Liu et al., 1995, 1996, 1997a, 1997b), both the roots and shoots were significantly reduced (Foy and Murray, 1998a, 1998b; Liu et al., 1995, 1996, 1997a, 1997b; Murray and Foy, 1978).

Root and shoot ratio is another parameter to compare the relative reduction of root or shoot. Significant changes were found among all cultivars except 'FMC 3-91' with 5- to 50fold increase of shoot/root ratios compared with the control. The $\mathrm{pH}$ of the control was 4.0 and that is a stressful condition for most plants even without Al existence. Significant differences found were obviously due to the Al toxic effect along on the roots and shoots.

The acid Tatum soil culture. Significant differences were found either through 28 day screening and 78 day screening (Table 2 and 3 ). Similar to the results of the solution screening, 'Guymon' and 'OKS 91-11' were sensitive cultivars compared to 'Cheyenne', 'OKS 91-1', and several others. The correlations between different screening methods were significant ( $r=0.46$ to 0.89 at $p<0.05$ to 0.0001 ).

The shoot/root ratio was not the same as the results of the solution culture and most the cultivars exhibited a reduced shoot/root ratio. It clearly indicates that shoot growth was significantly reduced as well. What caused the decreased shoot/ratio compared with the control remains unclear. However, based on the 78 day acid Tatum soil screening, the relative root mass and relative shoot mass was highly correlated $(r=0.89$ at $p<$ $0.0001)$. Short, thick, and swollen roots were observed with most cultivars after growing in Al treated media.

Slightly increased root growth was found only with 'Cheyenne' and 'OKS 91-1' and similar slight increase was found among kentucky bluegrass and hard fescue cultivars (Liu et al., 1995, 1996). Even some results indicate the beneficial effects of lower concentration of Al among other plants (Marschner, 1995), there was not enough evidence among the turfgrasses studied to support the beneficial effects of Al. The study by Vinceli and Williams (1998) indicates the beneficial lower soil $\mathrm{pH}$ (5.3 to 5.6) for reducing spring dead spot (Ophiospharella herpotricha and O. korre) among of bermudagrass and future investigations are needed.

\section{Conclusions}

Seeded bermudagrasses differ in Al resistance based on the greenhouse screenings using different screening media. Root and shoot growth reductions prove the Al toxicity to sensitive seeded bermudagrass cultivars. The results indicate that the genetic diversity in $\mathrm{Al}$ resistance exists among seeded bermudagrass and the future enhancement of bermudagrass for $\mathrm{Al}$ resistance is promising.

\section{Literature Cited}

Andersson, M. 1988. Toxicity and tolerance of aluminum in vascular plants. Water, Air, and Soil Pollution. 39:449-462.

De la Fuente, J.M., V. Ramrez-Rodiguez, J.L. Cabrera-Ponce, and L. Herrera-Estrella. 1997. Aluminum tolerance in transgenic plants by alteration of citrate synthesis. Science 276:1566-1568.

De la Fuente-Martinez, J.M. and L. Herrera-Estrella. 1999. Advances in the understanding of aluminum toxicity and the development of aluminum tolerant transgenic plants. Adv. Agron. 66:103-120.

Duncan, R.R. 2000. Plant tolerance to acid soil constraints: Genetic resources, breeding methodology, and plant improvement. In: R.E. Wilkinson (ed.). Plant environment interaction. 2nd ed. Marcel Dekker Inc., New York.

Duncan, R.R. and L.M. Shuman. 1993. Acid soil stress response of zoysiagrass. Intl. Turfgrass Soc. Res. J. 7:805-811.

Duncan, R.R. and R.N. Carrow. 1999. Turfgrass molecular genetic improvement for abiotic/edaphic stress resistance. Adv. Agron. 67:233-305.

Ezaki, B.M. Sivaguru, Y. Ezaki, H. Matsomoto, and R.C. Gardner. 1999. Acquisition of aluminum tolerance in Saccharomyces cerevisiae by expression of the $B c B$ or $N t G D I 1$ gene derived from plants. FEMS Microbial Lett. 171:81-87.

Ezaki, B., R.C. Gardner, Y.Ezaki, and H. Matsumoto. 2000. Expression of aluminum-induced genes in transgenic arabidopsis plants can ameliorate aluminum stress and/or oxidative stress. Plant Physiol. 122:657-665.

Foy, C.D., R.L. Chaney, and M.C. White. 1978. The physiology of metal toxicity in plants. Annu. Rev. Plant Physiol. 29:511-66.

Foy, C.D. 1988. Plant adaptation to acid, aluminum-toxic soils. Commun. Soil Sci. Plant Anal. 19:959-987.

Foy, C.D. 1992. Soil chemical factors limiting plant root growth. In: J.L. Hatfield and B.A. Stewart (eds.). Limitations to plant growth. Adv. Soil Sci. 19:97-149.
Foy, C.D. and J.J. Murray. 1998a. Developing aluminum-tolerant strains of tall fescue for acid soils. J. Plant Nutr. 21(6):1301-1325.

Foy, C.D. and J.J. Murray. 1998b. Responses of kentucky bluegrass cultivars to excess aluminum in nutrient solutions. J. Plant Nutr. 21(9):1967-1983.

Hoagland, D. R. and D. I. Arnon. 1950. The waterculture methods for growing plants without soil. Calif. Agr. Expt. Sta. Circ. 347.

Kochian, L.V. and D.L. Jones. 1997. Aluminum toxicity and resistance in plants. In: R.A. Yokel and M.S. Golub (eds.). Research issues in aluminum toxicity. Taylor \& Francis Publ., Wash., D.C.

Kochian, L.V. 1995. Cellular mechanisms of aluminum toxicity and resistance in plants. Annu. Rev. Plant Physiol. Plant Mol. Biol. 46:237-260.

Kochian, L.V., O.A. Hoekenga, and M.A. Pineros. 2004. How do crop plants tolerate acid soils? Mechanisms of aluminum tolerance and phosphorus efficiency. Annu. Rev. Plant. Plant. Biol. 55:459-493.

Liu, H. 2001. Soil acidity and aluminum toxicity response in turfgrass. Intl. Turfgrass Soc. Res. J. 9:180-188.

Liu, H., J.R. Heckman, and J.A. Murphy. 1997a. Greenhouse screening of turfgrasses for aluminum tolerance. Intl. Turfgrass Soc. Res. J. 8:719-728.

Liu, H., J.R. Heckman, and J.A. Murphy. 1997b. Aluminum tolerance among genotypes of Agrostis species. International Turfgrass Society Research Journal 8:729-734.

Liu, H., J.R. Heckman, and J.A. Murphy. 1996. Screening fine fescues for aluminum tolerance. J. Plant Nutr. 19(5):677-688.

Liu, H., J.R. Heckman, and J.A. Murphy. 1995. Screening kentucky bluegrass for aluminum tolerance. J. Plant Nutr. 18(9):1797-1814.

Marschner, H. 1995. Mineral nutrition of higher plants. 2nd ed. Academic Press, New York.

Murray, J.J. and C.D. Foy. 1978. Differential tolerances of turfgrass cultivars to an acid soil high in exchangeable aluminum. Agron. J. 70:769-774.

Taliaferro, C.M. 1995. Diversity and vulnerability of bermuda turfgrass species. Crop Sci. 35:327-332.

Taylor, G.J. 1988. The physiology of aluminum tolerance in higher plants. Commun. Soil Sci. Plant Anal. 19:1179-1194.

Taylor, G.J. 1991. Current views of the aluminum stress response: The physiological basis of tolerance. Curr. Top. Plant Biochem. Physiol. 10:57-93.

Vinceli, P. and D. Williams. 1998. Managing spring dead spot of bermudagrass. Golf Course Mgt. (May):49-53. 